\title{
D-vitamin és kalcium a klinikai evidenciák tükrében
}

\author{
Bajnok László dr. \\ Pécsi Tudományegyetem, Általános Orvostudományi Kar, I. Belgyógyászati Klinika, Pécs \\ A jelen tudományos közleményt a szerző a Pécsi Tudományegyetem alapitásának \\ 650. évfordulója tiszteletére közli.
}

\begin{abstract}
A biológiai mechanizmusok, ökológiai és megfigyeléses vizsgálatok a D-vitamin-hiány morbiditást és mortalitást fokozó hatását jelzik, míg - a zömmel D-vitamin-hiányosokon végzett - ellenőrzött, véletlen besorolásos, pótlásos tanulmányok eredménye javarészt negatív, bizonyos marginális előnyökkel. Utóbbiak elsősorban az idősotthonban élők elesésének és csonttörésének megelőzésére látszanak korlátozódni; a megfigyelt mérsékelt mortalitáscsökkenés vitatott statisztikai szignifikanciájú. A tisztánlátást az is zavarja, hogy az intervenciós vizsgálatok általában nem extraossealis elsődleges végpontúak voltak. Az ideális szérum-25-hidroxi-D-vitamin-szinttel kapcsolatban is jelentős az ellentmondás: egyértelmúen J görbe mutatkozik, de az optimális tartomány bizonytalan. Mindez az ajánlások szintjén is megjelenik, amelyek azonban abban egységesek, hogy nem javasolnak (i) populációszintű szürést és (ii) - az eleséseken kívül - extraossealis célzattal D-vitamin-pótlást. Bizonyos vizsgálatok arra utalnak, hogy a kalciumpótlás gyakoribbá teszi a cardiovascularis eseményeket, míg mások ilyen szempontból semleges hatást jeleznek. Több, kifejezetten extraossealis betegségre tervezett D-vitaminos vizsgálat van folyamatban. Orv. Hetil., 2016, 157(31), $1242-1247$.
\end{abstract}

Kulcsszavak: D-vitamin-pótlás, kalciumpótlás, 25-hidroxi-D-vitamin-szérumszint, metaanalízisek, ajánlások

\section{Vitamin $\mathrm{D}$ and calcium in the mirror of clinical evidence}

The biological mechanisms, ecological and observational studies indicate increased morbidity and mortality in vitamin D deficiency, while the controlled, randomized supplementation trials - carried out mostly in vitamin D deficient patients - have shown no or some marginal benefits, mostly in preventing institutionalized elderly individuals' falls and fractures. Clarity is also disturbed by that the primary end points of intervention studies were generally not extraskeletal. The ideal serum 25 -hydroxyvitamin D levels also considerably controversial: there is clearly a J-curve, but the optimal range is uncertain. All of these uncertainties appear also in the vitamin $\mathrm{D}$ guidelines which are, however, concordant in that they do not recommend (i) a population-wide screening and (ii) vitamin D supplementation with extraskeletal aim - beyond the prevention of falls. Certain studies suggest that calcium supplementation increases the incidence of cardiovascular events, while others show a neutral effect in this respect. There are several ongoing vitamin D studies directly designed for extraskeletal events.

Keywords: vitamin D supplementation, calcium supplementation, 25-hydroxyvitamin D serum levels, metaanalyses, recommendations

Bajnok, L. [Vitamin D and calcium in the mirror of clinical evidence]. Orv. Hetil., 2016, 157(31), 1242-1247.

(Beérkezett: 2016. február 9.; elfogadva: 2016. május 24.)

\section{Rövidítések}

$\mathrm{IOF}=$ International Osteoporosis Foundation; IOM = Institute of Medicine; USPSTF $=$ U.S. Preventive Services Task Force
A D-vitamin alapvető fontosságú, ősi hormonként számos folyamatot szabályoz, extraossealisan is: a csontmineralizáció befolyásolásán túl gátolja a parathormon-elválasztást, az adaptív immunitást és a sejtosztódást, míg 
serkenti az inzulin elválasztását, a veleszületett immunitást és a sejtdifferenciálódást [1]. A D-vitamin a keringésben javarészt 25-hidroxi-D-vitamin formájában van jelen, szérumszintje a D-vitamin-ellátottság mutatója. Az elégtelen D-vitamin-szint gyakori a lakosság körében. Ezek alapján is jogos feltételezni, hogy a D-vitamin-pótlás befolyásolja bizonyos betegségek előfordulását. Figyelembe kell azonban venni, hogy az eddigi, D-vitaminnal végzett véletlen besorolásos, ellenőrzött vizsgálatok szelektált betegcsoportokon (idősek, nagyobbrészt nők) történtek, vegyes minőségűek voltak, s általában nem extraossealis - így cardiovascularis - esemény volt az elsődleges végpontjuk.

\section{Az újabb nagy metaanalízisek tanulságai}

A U.S. Preventive Services Task Force (USPSTF) - az 1984-ben alakult, független és önkéntes nemzeti szakértőkből álló, nagy tekintélyű grémium - 2011-ben áttekintette a D-vitamin-pótlás csonttörési kockázatot és malignus betegségeket befolyásoló hatását [2]. Ennek során bizonyos adatok arra utaltak, hogy $1000 \mathrm{E} /$ nap körüli dózisú D-vitamin mérsékelheti a rákkockázatot; ezzel ellentmondásban viszont megfigyeléses vizsgálatok a magas 25-hidroxi-D-vitamin-szint és a carcinomagyakoriság között pozitív összefüggést jeleztek. Összességében nem találták kellően meggyőzőnek a D-vitaminpótlás carcinomakockázatot csökkentő hatása mellett szóló adatokat egy pozitív ajánlás megfogalmazásához [2]. A csonttörés vonatkozásában a bizottság tagjai random hatásmodellek metaanalízise alapján - arra a következtetésre jutottak, hogy a D-vitamin- és kalciumpótlás idöseknél csökkentheti a kockázatot, de számottevő különbség mutatható ki az önállóan vagy ápolási intézményben élőkön végzett vizsgálatok között: szignifikáns hatás csak az utóbbi populáción végzett vizsgálatok öszszesítésében volt. Elképzelhető, hogy a D-vitamin időszakos nagy adagokban történó alkalmazása lerontja a pótlás hatását, mert ilyenkor átmenetileg fokozódhat a csontvesztés, növelve a törések számát, azonban ezzel kapcsolatban nincsenek véletlen besorolásos vizsgálatok, így ez a feltételezés jelenleg feltételezés marad.

Egy új-zélandi munkacsoport - D-vitamin-pótlással végzett vizsgálatok metaanalíziséből származó - 2013-as konklúziója az volt, hogy a kezelésnek - szemben a lentebb tárgyalt kalciumpótlással - nincs érdemi hatása a csontsürüségre (a combnyak esetén mutatkozó tendencia $95 \%$ CI-értéke $0,2-1,4$ volt [3]).

Autier és mtsai is 2013-ban jelentették meg a D-vitamin 18 évnél idősebbek extraossealis hatásaira vonatkozó elemzésüket [4], amelyben számos prospektív vizsgálat igazolt fordított kapcsolatot a 25-hidroxi-D-vitamin szérumszintje és a következő paraméterek között: cardiovascularis betegségek, dyslipidaemia, gyulladásos paraméterek, dysglykaemia és súlygyarapodás, infekciók, sclerosis multiplex, hangulatzavarok, kognitív zavarok, izomerő és koordináció, valamint a mortalitás. A daga- natos betegségek közül csak a colorectalis carcinoma gyakorisága mutatott fordított összefüggést a magas 25-hidroxi-D-vitamin-szérumszinttel. Ugyanakkor a Dvitamin-pótlással végzett véletlen besorolásos, ellenőrzött vizsgálatok mindezt nem igazolták vissza: a fentiek közül csak az idősek mortalitásának mérsékelt csökkenése volt megfigyelhető. A megfigyeléses és intervenciós vizsgálatok közötti ellentmondás alapján felvetették, hogy az alacsony D-vitamin-szérumszint csak a rossz egészségi állapot jele és nem okozója.

Chowdhury és mtsai - hasonló metaanalízist végezve - hasonló eredményre jutottak [5], mint Autier és mtsai. Ök azonban az alkalmazott D-vitamin-készítmények szerint is elemezték a vizsgálatokat, s azt találták, hogy a mortalitás javulása csak a $\mathrm{D}_{3}$-vitaminra látszik korlátozódni, míg a kisebb dózisú $\mathrm{D}_{2}$-vitamin alkalmazásával végzett, rövidebb követési idejű vizsgálatokban a mortalitás magasabb volt. Konklúziójukban a széles körü Dvitamin-pótlás helyett további vizsgálatokat javasoltak.

Bolland és mtsai trial sequential metaanalízist végeztek, ami (elvileg) alkalmas annak statisztikai eldöntésére, hogy a rendelkezésre álló adatok mikor elegendőek konklúzió levonásához és hogy további vizsgálatoktól várható-e ennek változása [6]. Az adatokat a kalciumpótlás szerint is értékelték. Elemzésükbe - a coronaria és cerebrovascularis, valamint daganatos megbetegedések mellett - a csonttöréseket is bevonták. Egyetlen pozitívumot találtak: a nem önállóan élő idősek combnyaktörésének alacsonyabb gyakoriságát, ha kalciumpótlás is történt. A D-vitamin-pótlás egyéb előnyös hatását nemcsak hogy nem tudták kimutatni, hanem azt is valószínüsítették, hogy ezen eredményeken érdemben további vizsgálatok sem változtatnak. A mortalitás D-vitaminpótlás melletti csökkenését hagyományos metaanalízissel maguk is szignifikánsnak találták, de az álpozitív eredményekre kevésbé érzékeny, úgynevezett trial sequential elemzésben ez a hatás a bizonytalan tartományban maradt. Bár Bolland és mtsai - statisztikai elemzésük alapján - feleslegesnek ítélték további tanulmányok folytatását [6], (szerencsére) több olyan nagy (összesen 100000 körüli beteg bevonásával), 50 év felettieken végzett Dvitamin-pótlásos vizsgálat van folyamatban, amelyek elsődleges célja a következő incidenciák tisztázása: daganatos, illetve cardiovascularis betegségek, diabetes, infekciók, kognitív zavarok és csonttörések [7].

A D-vitamin-bevitel cardiovascularis eseményekre és mortalitásra gyakorolt hatását az egyidejü kalciumpótlás is befolyásolhatja, amit lentebb, a kalciumpótlás hatásainál tárgyalunk.

\section{Egyéb extraossealis hatásokat vizsgáló tanulmányok}

A fentiekből következően a colorectalis carcinoma incidenciájának D-vitamin-pótlás melletti alakulása különösen izgalmas kérdés. Egy kifejezetten erre a célra tervezett, vastagbélpolipban szenvedőkön végzett új 
vizsgálatban azonban nem volt kimutatható a D-vitamin-pótlás protektív hatása [8]. Beveridge és mtsai pedig egy friss metaanalízisben a $\mathrm{D}$-vitamin-pótlás vérnyomáscsökkentő hatását nem tudták igazolni [9].

Ellentmondásosak a D-vitamin-pótlás légúti fertőzések megelőzésében játszott szerepére vonatkozó adatok: egy metaanalízis hatásosnak találta ezt, de jelentős heterogenitás volt az elemzett tanulmányokban [10]. Az ezt követően megjelent, negatív eredményű nagy vizsgálatuk alapján Rees és mtsai is áttekintették a kérdést [11]. Azt találták, hogy a jó minőségű véletlen besorolásos, ellenőrzött vizsgálatok semleges eredményưek, hangsúlyozva annak potenciális jelentőségét, hogy D-vitaminhiányos populáción történt-e az adott study.

Az intenzív osztályos kezelést igénylők között különösen gyakori a D-vitamin-hiány. Ennek ellenére egy megfelelő statisztikai erejü intervenciós vizsgálat nem tudta kimutatni az elsődleges végpont, a kórházi kezelés hoszszának javulását egy D-vitamin-hiányos kritikus állapotú populáción [12].

Különösen várakozásteli a sclerosis multiplex progressziójának véletlen besorolásos, ellenőrzött vizsgálatokban D-vitaminnal történő potenciális befolyásolhatósága (PrevANZ és D-Lay-MS trials).

\section{A kalciumpótlás klinikai hatásai}

A kalciumpótlás csonttörési kockázatra gyakorolt hatása ellentmondásos az irodalomban: egy kilenc véletlen besorolásos, ellenőrzött vizsgálat metaanalízéséból származó tanulmány 10\% kockázatcsökkenést jelzett [13], míg egy új-zélandi kutatócsoport - három vizsgálat összesítése alapján - a csípőtáji törések 50\%-os növekedését találta, ha D-vitamin nélkül történt a kalciumbevitel [14]. A kutatócsoport saját vizsgálatában a kalciumpótlás szemben a fentebb tárgyalt D-vitamin-pótlásos metaanalízissel - tartósan csökkentette az időskori csontvesztést és csontturnovert [15], bár a csonttörések csökkenését nem tudták kimutatni.

Az új-zélandi kutatócsoport 2008-ban jelentette meg a kalciumpótlási tanulmány másik, cardiovascularis hatásokra vonatkozó részét [16]. A vizsgálat elsődleges célja - mint fentebb jeleztük - a kalciumpótlás tartós csonthatásainak tisztázása volt, de előzetes pozitív cardiovascularis várakozások miatt ezen eseményeket is a korábbi, hasonló vizsgálatoknál intenzívebben monitorozták. Az addig ismert megfigyeléses és - vérnyomás- és lipidparaméterekre vonatkozó - patogenetikai vizsgálatok ugyanis rendre kedvező eredményűek voltak. Meglepetésre azonban a cardiovascularis események gyakoribbá válásának tendenciáját figyelték meg [16]. Ez a szerzőket metaanalízis készítésére sarkallta, amiben - a saját vizsgálatukhoz hasonlóan - a cardiovascularis kockázat kalciumpótlás melletti fokozódását akkor is meg tudták erősíteni [17], ha egyidejüleg D-vitamin-alkalmazás is történt. Az elemzés többféle technikai problémát vetett fel, s erős vita övezte $[18,19]$; más metaanalízisek pedig nem erő- sítették meg az aggodalmakat [20, 21]. Az American Society for Bone and Mineral Research 2012-ben úgy foglalt állást, hogy az adatok elégtelenek a kalciumpótlás cardiovascularis kockázatot okozó hatásának bizonyításához [22]. Egyes szakértők - a biztonság kedvéért, a gyógyszerkészítményekkel szemben - a természetes, étrendi kalciumpótlást javasolják [23].

Ellentmondásosak a kalciumpótlással kapcsolatos prospektív megfigyeléses vizsgálatok is: a semleges eredményüek mellett több is a cardiovascularis események vagy mortalitás növekedését jelezte [24-26]; egy frissen elemzett kohorszban azonban a mortalitás csökkenését lehetett kimutatni a D-vitamin- és kalciumpótlás kombinációja mellett (a D-vitamin magában semleges hatású volt) [27].

A kalcium biztonságossági kockázatát indirekt módon, ellenkező oldalról közelítette meg a - többek között - kalciumot kötő, kelátképző EDTA-infúzió időszakos alkalmazásával, posztinfarktusos betegeken végzett TACT-vizsgálat, ami a cardiovascularis események intervenció melletti csökkenését mutatta [28].

Összefoglalva: A kalciumpótlás biztonságosságát jelenleg is bizonytalanság övezi [18, 23]. Hangsúlyozni kell azonban, hogy a biszfoszfonátkezelés mellé adott adjuváns D-vitamin- és kalciumpótlással kapcsolatban nem merült fel cardiovascularis biztonsági aggály [29].

\section{A nagy nemzetközi D-vitamin- és kalciumajánlások}

Az USPSTF 2013-ban ajánlást tett a D-vitamin és kalcium pótlására vonatkozóan [30]. Az adagok tekintetében az Institute of Medicine (IOM) állásfoglalására hivatkoznak, ami 19-70 év között napi 600 E D-vitamin bevitelét javasolja, 70 felett napi 800 E-et [31], míg kalciumból férfiaknak 70 éves korig, nőknek 50 éves korig 1000 mg-ot ajánl, ennél idősebbeknek 1200 mg-ot. (Az európai ajánlások csak 700-800 mg/nap kalciumot javasolnak.) Az USPSTF összességében és általánosságban nem javasolja férfiak és menopauza előtti, illetve nem ápolási intézményben élő menopauzában lévő nők primer prevenciós $\mathrm{D}$-vitamin- és kalciumpótlását - igaz, a pótlás ellen sem foglaltak állást, hanem további vizsgálatokat sürgettek a menopauzában lévő nők és idősebb férfiak D-vitamin- és kalciumpótlásának csonttörésre gyakorolt hatásával kapcsolatban. Bár a bizottság elismerte a megfelelő kalciumbevitel csontokra gyakorolt pozitív hatását, ilyen szempontból veszélyeztetett betegcsoportokat nem definiált. Explicite csak a kis dózisú D-vitamin (<400 E/nap) és kalcium (<1000 mg) alkalmazását nem javasolják, pozitív hatás hiányában és fokozott vesekőkockázat miatt. Ez utóbbival az International Osteoporosis Foundation (IOF) is egyetértett az USPSTF-ajánláshoz füzött kommentárjában [32], de a 800 E/nap, 60 év felett 800-1000 E/nap D-vitamin-adagok általános törési kockázatot mérséklő hatását meggyőzőnek minősítették. A D-vitamin-bevitelt egyébként az IOF elsősorban természetes módon javasolja - étellel és napozás for- 
májában - s csak a fennmaradó hiány kompenzálását gyógyszeresen. Az USPSTF is elegendőnek ítélte viszont a D-vitamin-pótlás hatékonyságára vonatkozó bizonyítékokat a 65 évnél idősebbek elesésének megelőzésére, ha olyan hajlamosító egyéb tényező is kimutatható, mint előzetes elesés vagy D-vitamin-hiány [30]. Az Endocrine Society (ENDO) ajánlása ezzel szemben az elesés megelőzésére 65 év felett általánosan - nemcsak az USPSTF által elfogadott kockázati tényezők esetén - javasolja a D-vitamin-pótlást, $800 \mathrm{E} /$ nap adagban [33]. Ugyanakkor az ENDO sem javasol extraossealis célzattal extrém adagú D-vitamin-bevitelt. Ennek felel meg az európai diabetesajánlás is (EASD/ESC), ami határozottan állást foglal a cardiovascularis célból történő vitamin- és nyomelempótlás ellen (Class III) [34]. (Ezzel összhangban egy 2013-as metaanalízis az antioxidáns vitaminok semleges vagy mortalitást fokozó hatását jelezte [35].)

Az USPSTF 2015-ben adta ki azon nem várandós, 18 év feletti egyének D-vitamin-szűrésére vonatkozó ajánlását, akiknél nincsenek D-vitamin-hiány tünetei vagy erre hajlamosító tényezők (például endokrin, csont- vagy autoimmun betegség) [36]. Problémát jelent a standardizált laboratóriumi szürómódszerek hiánya is, de a rendelkezésre álló adatok nem bizonyultak elegendőnek egy ilyesfajta szürési ajánlás megfogalmazásához. Ez lényegében megegyezik az American Academy of Family Physicians D-vitamin-szürés előnyének és veszélyének mérlegelésével kapcsolatos korábbi következtetésével [37]. Ugyanakkor az USPSTF-bizottság tagjai elismerik, hogy a D-vitamin-hiány kockázata nagyobb lehet azoknál a személyeknél, akiknél alacsony a D-vitamin-bevitel, csökkent a D-vitamin-felszívódás vagy minimális a napsugárzás hatása. Másrészt viszont az USPSTF-szakértők nem találták meggyőzőnek, hogy az elhízással vagy sötétebb bőrszínnel kapcsolatos alacsonyabb szérum-25-hidroxi-D-vitamin-szint valódi D-vitamin-hiányt tükröz, kedvezőtlen klinikai kimenetelre hajlamosítva [36]. Ez éles ellentétben áll az ENDO ajánlásával, ami az elhízottak D-vitamin-hiányának rendezése után igen nagy fenntartó adagokat (3-6000 E/nap) javasol, arra hivatkozva, hogy a D-vitamin-pótlás hatására az elhízottak 25-hidroxi-D-vitamin-szintje a nem elhízottakhoz viszonyítva 50\%-kal nagyobb mértékben nem tud emelkedni [33]. Itt kell megjegyezni, hogy bár az ENDO az USPSTF-nél szélesebb körben tartja indokoltnak a 25-hidroxi-D-vitamin meghatározását, az ENDO sem javasol populációs szintü, általános szürést.

Az USPSTF szakértői bizonytalannak ítélték az 50 nmol/1 25-hidroxi-D-vitamin-hiány-határ feletti optimális tartományt is [36]. Ez harmonizál az IOM állásfoglalásával [31], és szintén éles ellentétben áll az ENDO ajánlásával, ami az 50 és $75 \mathrm{nmol} / 1$ közötti értékeket elégtelenségként definiálja [33]. S bár nincsenek céltartomány elérése szerint randomizált vizsgálatok sem [38], ennek evidenciaalapú indoklásaként az ENDO szakértői hangsúlyozták, hogy csak $75 \mathrm{nmol} / 1$ feletti 25-hidroxiD-vitamin-szintet elérő - egyébként 7-800 E/nap $\mathrm{D}_{3}$ - vitamin-adaggal végzett - vizsgálatokban lehetett kimutatni csonttörési kockázatot mérséklő hatást [39], nem ápolási intézményben élőkön és kalciumpótlástól függetlenül is [40]. Meg kell jegyezni, hogy egyes szakértők éppenséggel a 100-150 nmol/l tartományt tekintik célnak [41].

Az ENDO munkabizottsága szerint az általuk megfelelőnek ítélt $75 \mathrm{nmol} / 1$ feletti érték biztosításához 1500-2000 E/nap D-vitamin pótlására van szükség [33]. Ezt a fenntartó adagot javasolják a D-vitamin-deficientia megszüntetése után is. Elismerik ugyanakkor, hogy az ezekre vonatkozó bizonyítékok gyengék - és ennek megfelelően ezen nagy adagra vonatkozó javaslatuk általánosságban nem erős, csak a veszélyeztetett csoportokban. Benelux szakértőket az ENDO-ajánlás nagy Dvitamin-adagjai arra sarkalltak, hogy maguk is áttekintsék a rendelkezésre álló adatokat [42]. Arra a következtetésre jutottak, hogy az általában legalább $50 \mathrm{nmol} / \mathrm{l}$ 25-hidroxi-D-vitamin-szintet biztosító 5-700 E/nap $\mathrm{D}_{3}$-vitamin bevitele elegendő, s csak az $50 \mathrm{nmol} / 1$ alatti szérumszintek esetében lehet kimutatni a vastagbélrák, infekciók, cardiovascularis és anyagcsere-betegségek fokozott kockázatát. Felhívják arra is a figyelmet, hogy az automatikus mérési módszerek pontatlansága a D-vitamin-hiány túlbecsléséhez vezethet, illetve, hogy a túlzott D-vitamin-ellátottság fokozott csonttörési, elesési, daganatos és cardiovascularis vagy akár mortalitási kockázatot hordozhat.

\section{Az optimális 25-hidroxi-D-vitamin- tartománnyal kapcsolatos újabb adatok}

Az optimális 25-hidroxi-D-vitamin-tartomány meghatározása körüli - így az USPSTF részéről is mutatkozó, fentebb részletezett - tartózkodó attitúd jogosságát igazolta egy friss, véletlen besorolásos, ellenőrzött vizsgálat, amelynek elsődleges végpontját, az idősek elesésének gyakoriságát nagy adagú D-vitamin-pótlás gyakoribbá tette [43]. A studyban a kontrollt a hagyományos, 800 $\mathrm{E} /$ nap átlagúnak megfelelő $\mathrm{D}$-vitamin-pótlás képezte, ami - mint korábban ismertettük, az előzetes vizsgálatok alapján - az időskori elesések prevenciója tekintetében hatékonynak tekintett dózis. (Meg kell jegyezni, hogy az időskori elesések megelőzésében a $800 \mathrm{E} /$ nap adag két friss, véletlen besorolásos, placebokontrollos vizsgálatban sem volt hatásos [44, 45], s már egy 2010-ben megjelent tanulmány is az elesések - és csonttörések - gyakoriságának növekedését jelezte nagy dózisú D-vitamin mellett [46].) A mostani, Bischoff-Ferrari-vizsgálat 800 $\mathrm{E} /$ nap adagja valamivel $75 \mathrm{nmol} / \mathrm{l}$ feletti szérum25-hidroxi-D-vitamin medián értéket biztosított, míg az aktív ág nagy dózisú D-vitamin-pótlása 90-115 nmol/1 közötti szérum-25-hidroxi-D-vitamin-mediánt [43]. A legmeglepőbb eredmény talán az volt, hogy az ENDO szerint „elégtelen” tartományba (50-75 nmol/1 közé) eső, legalacsonyabb szérum-25-hidroxi-D-vitamin-kvintilishez képest a legmagasabb 5,5-szeres kockázatot je- 
lentett az elesések vonatkozásában. Ezek alapján már maga Bischoff-Ferrari is - az ENDO-ajánlás prominense - 50-75 nmol/1 közötti szérum-25-hidroxi-D-vitamintartományt tart optimálisnak. Ezzel harmonizál az az epidemiológiai elemzés, amiben akut coronariaszindróma szempontjából legelőnyösebb az 50-90 nmol/1 közötti tartomány volt: nemcsak ez alatt, hanem e felett is szignifikánsan nagyobb volt a morbiditás és mortalitás [47].

Ha valóban 50-75 nmol/1 közötti az optimális 25-hidroxi-D-vitamin-tartomány, akkor viszont - populációszintű $\mathrm{D}$-vitamin-pótlás tervezése esetén - létjogosultsága lehet a szélesebb körű 25-hidroxi-D-vitaminszû́résnek, mert a népesség jelentős hányada az optimális tartományba esik, akiknél nem indokolt, sőt veszélyes lehet a pótlás.

\section{Következtetések}

A D-vitamin-pótlás hatása még D-vitamin-hiányos idősek elesése vagy csonttörése megelőzésének tekintetében sem egyértelmú.

Erősen vitatott a szakirodalomban, hogy az 50 és 75 nmol/1 közötti 25-hidroxi-D-vitamin-szint elégtelenség, esetleg hiány jele vagy éppenséggel céltartomány. Ez a bizonytalanság a javasolt adagok vonatkozásában is kifejezésre jut. Friss adatok paradigmaváltás előtti állapotot sejtetnek.

A mérvadó nemzetközi ajánlások egyike sem javasol rutinszerű D-vitamin-alkalmazást - elesésprevención túli - extraossealis célzattal.

A kalciumpótlással kapcsolatos adatok sem elegendőek a cardiovascularis biztonságosság vagy kockázat egyértelmú megállapításához.

A szakértők megosztottságára jellemző, hogy míg az IOM általánosan javasol, életkortól függően 600-800 E/nap D-vitamin-pótlást, az USPSTF-ajánlás szerkesztőségi kommentárja szerint: „miközben várjuk a további vizsgálatok eredményeit, az USPSTF óvatos, tényeken alapuló tanácsai arra kell, hogy ösztönözzék a klinikusokat, hogy alaposan gondolják meg az egészséges egyéneknek javasolt kalcium- és D-vitamin-pótlást” [48].

Több, kifejezetten cardiovascularis és immunológiai betegségre, diabetes-, infekció- és halálozási gyakoriságra, kognitív zavarokra és csonttörésekre tervezett D-vitamin-vizsgálat van folyamatban. Remélhetőleg ezek segítenek a kétségek eloszlatásában.

Anyagi támogatás: A közlemény megírása és a kapcsolódó kutatómunka anyagi támogatásban nem részesült.

A szerző a cikk végleges változatát elolvasta és jóváhagyta.

Érdekeltségek: A szerzőnek nincsenek érdekeltségei.

\section{Irodalom}

[1] Norman, A. W., Bouillon, R.: Vitamin D nutritional policy needs a vision for the future. Exp. Biol. Med. (Maywood), 2010, 235(9), 1034-1045.

[2] Chung, M., Lee, J., Terasawa, T., et al.: Vitamin D with or without calcium supplementation for prevention of cancer and fractures: an updated meta-analysis for the U.S. Preventive Services Task Force. Ann. Intern. Med., 2011, 155(12), 827-838.

[3] Reid, I. R., Bolland, M. J., Grey, A.: Effects of vitamin D supplements on bone mineral density: a systematic review and metaanalysis. Lancet, 2014, 383(9912), 146-155. (Published online: 11 October 2013)

[4] Autier, P., Boniol, M., Pizot, C., et al.: Vitamin D status and ill health: a systematic review. Lancet Diabetes Endocrinol., 2014, 2(1), 76-89. (Published online: 06 December 2013)

[5] Chowdhury, R., Kunutsor, S., Vitezova, A., et al.: Vitamin D and risk of cause specific death: systematic review and meta-analysis of observational cohort and randomised intervention studies. BMJ, 2014, 348, g1903.

[6] Bolland, M. J., Grey, A., Gamble, G. D., et al.: The effect of vitamin D supplementation on skeletal, vascular, or cancer outcomes: a trial sequential meta-analysis. Lancet Diabetes Endocrinol., 2014, 2(4), 307-320.

[7] Kupferschmidt, K.: Uncertain verdict as vitamin $\mathrm{D}$ goes on trial. Science, 2012, 337(6101), 1476-178.

[8] Baron, J. A., Barry, E. L., Mott, L. A., et al.: A trial of calcium and vitamin $\mathrm{D}$ for the prevention of colorectal adenomas. N. Engl. J. Med., 2015, 373(16), 1519-1530.

[9] Beveridge, L. A., Struthers, A. D., Khan, F., et al., D-PRESSURE Collaboration: Effect of vitamin D supplementation on blood pressure: a systematic review and meta-analysis incorporating individual patient data. JAMA Intern. Med., 2015, 175(5), 745754.

[10] Bergman, P., Lindh, A. U., Björkhem-Bergman, L., et al.: Vitamin $\mathrm{D}$ and respiratory tract infections: A systematic review and metaanalysis of randomized controlled trials. PLoS ONE, 2013, 8(6), e65835.

[11] Rees, J. R., Hendricks, K., Barry, E. L., et al.: Vitamin D3 supplementation and upper respiratory tract infections in a randomized, controlled trial. Clin. Infect. Dis., 2013, 57(10), 1384-1392.

[12] Amrein, K., Schnedl, C., Holl, A., et al.: Effect of high-dose vitamin D3 on hospital length of stay in critically ill patients with vitamin D deficiency: the VITdAL-ICU randomized clinical trial. JAMA, 2014, 312(15), 1520-1530.

[13] Tang, B. M., Eslick, G. D., Nowson, C., et al.: Use of calcium or calcium in combination with vitamin $\mathrm{D}$ supplementation to prevent fractures and bone loss in people aged 50 years and older: a meta-analysis. Lancet, 2007, 370(9588), 657-666.

[14] Reid, I. R., Bolland, M. J., Grey, A.: Effect of calcium supplementation on hip fractures. Osteoporos. Int., 2008, 19(8), 11191123.

[15] Reid, I. R., Mason, B., Horne, A., et al.: Randomized controlled trial of calcium in healthy older women. Am. J. Med., 2006, $119(9), 777-785$.

[16] Bolland, M. J., Barber, P. A., Doughty, R. N., et al.: Vascular events in healthy older women receiving calcium supplementation: randomized controlled trial. BMJ, 2008, 336(7638), 262266.

[17] Bolland, M. J., Grey, A., Avenell, A., et al.: Calcium supplements with or without vitamin $\mathrm{D}$ and risk of cardiovascular events: reanalysis of the Women's Health Initiative limited access dataset and meta-analysis. BMJ, 2011, 342, d2040.

[18] Abrahamsen, B., Sahota, O.: Do calcium plus vitamin D supplements increase cardiovascular risk? BMJ, 2011, 342, d2080. 
[19] Hennekens, C. H., Barice, E. J.: Calcium supplements and risk of myocardial infarction: a hypothesis formulated but not yet adequately tested. Am. J. Med., 2011, 124(12), 1097-1098.

[20] Wang, L., Manson, J. E., Song, ., et al.: Systematic review: vitamin D and calcium supplementation in prevention of cardiovascular events. Ann. Intern. Med., 2010, 152(5), 315-323.

[21] Lewis, J. R., Radavelli-Bagatini, S., Rejnmark, L., et al.: The effects of calcium supplementation on verified coronary heart disease hospitalization and death in postmenopausal women: a collaborative meta-analysis of randomized controlled trials. J. Bone Miner. Res., 2015, 30(1), 165-175.

[22] Bockman, R. S., Zapalowski, C., Kiel, D. P., et al.: Commentary on calcium supplements and cardiovascular events. J. Clin. Densitom., 2012, 15(2), 130-134.

[23] Bawer, D. C.: Clinical practice. Calcium supplements and fracture prevention. N. Engl. J. Med., 2013, 369(16), 1537-1543.

[24] Michaëlsson, K., Melhus, H., Warensjö Lemming, E., et al.: Long term calcium intake and rates of all cause and cardiovascular mortality: community based prospective longitudinal cohort study. BMJ, 2013, 346, f228.

[25] Li, K., Kaaks, R., Linseisen, J., et al.: Associations of dietary calcium intake and calcium supplementation with myocardial infarction and stroke risk and overall cardiovascular mortality in the Heidelberg cohort of the European Prospective Investigation into Cancer and Nutrition study (EPIC-Heidelberg). Heart, 2012, 98(12), 920-925.

[26] Xiao, Q., Murphy, R. A., Houston, D. K., et al.: Dietary and supplemental calcium intake and cardiovascular disease mortality: the National Institutes of Health-AARP diet and health study. JAMA Intern. Med., 2013, 173(8), 639-646.

[27] Rejnmark, L., Avenell, A., Masud, T., et al.: Vitamin D with calcium reduces mortality: patient level pooled analysis of 70,528 patients from eight major vitamin D trials. J. Clin. Endocrinol. Metab., 2012, 97(8), 2670-2681.

[28] Lamas, G. A., Goertz, C., Boineau, R., et al.: Effect of disodium EDTA chelation regimen on cardiovascular events in patients with previous myocardial infarction: the TACT randomized trial. JAMA, 2013, 309(12), 1241-1250.

[29] Camm, J. A.: Review of the cardiovascular safety of zoledronic acid and other bisphosphonates for the treatment of osteoporosis. Clin. Ther., 2010, 32(3), 426-436.

[30] Moyer, V. A., U.S. Preventive Services Task Force: Vitamin D and calcium supplementation to prevent fractures in adults: U.S. Preventive Services Task Force recommendation statement. Ann. Intern. Med., 2013, 158(9), 691-696.

[31] Ross, A. C., Taylor, C. L., Yaktine, A. L., et al. (eds.), Committee to Review Dietary Reference Intakes for Vitamin D and Calcium; Institute of Medicine: Dietary Reference Intakes for Calcium and Vitamin D. National Academies Press, Washington, 2011. http://www.nap.edu/catalog/13050/dietary-reference-intakes-for-calcium-and-vitamin-d

[32] IOF comments on US Task Force recommendations regarding vitamin $\mathrm{D}$ and calcium supplementation. Accessed at www. iofbonehealth.org/iof-comments-us-task-force-recommendations-regarding-vitamin-d-and-calcium-supplementation on 1 May 2016.

[33] Holick, M. F., Binkley, N. C., Bischoff-Ferrari, H. A., et al.: Evaluation, treatment, and prevention of vitamin D deficiency: an Endocrine Society clinical practice guideline. J. Clin. Endocrinol. Metab., 2011, 96(7), 1911-1930.

[34] The Task Force on diabetes, pre-diabetes, and cardiovascular diseases of the European Society of Cardiology (ESC) and developed in collaboration with the European Association for the Study of Diabe- tes (EASD): ESC Guidelines on diabetes, pre-diabetes, and cardiovascular diseases developed in collaboration with the EASD. Eur. Heart J., 2013, 34(39), 3035-3087. Erratum: Eur. Heart J., 2014, 35(27), 1824.

[35] Bjelakovic, G., Nikolova, D., Glund, C.: Meta-regression analyses, meta-analyses, and trial sequential analyses of the effects of supplementation with beta-carotene, vitamin $\mathrm{A}$, and vitamin $\mathrm{E}$ singly or in different combinations on all-cause mortality: do we have evidence for lack of harm? PLoS ONE, 2013, 8(9), e74558.

[36] LeFevre, M. L., U.S. Preventive Services Task Force: Screening for vitamin D deficiency in adults: U.S. Preventive Services Task Force recommendation statement. Ann. Intern. Med., 2015, 162(2), 133-140.

[37] American Academy of Family Physicians: Recommendations by type: clinical preventive services. American Academy of Family Physicians, Leawood, KS, 2014. www.aafp.org/patient-care/ clinical-recommendations/cps.html

[38] Cummings, S. R., Kiel, D. P., Black, D. M.: Vitamin D supplementation and increased risk of falling: A cautionary tale of vitamin supplements retold. JAMA Intern. Med., 2016, 176(2), 171-172.

[39] Bischoff-Ferrari, H. A., Willett, W. C., Wong, J. B., et al.: Fracture prevention with vitamin $\mathrm{D}$ supplementation: a meta-analysis of randomized controlled trials. JAMA, 2005, 293(18), 22572264.

[40] Bischoff-Ferrari, H. A., Willett, W. C., Wong, J. B., et al.: Prevention of nonvertebral fractures with oral vitamin $\mathrm{D}$ and dose dependency: a meta-analysis of randomized controlled trials. Arch. Intern. Med., 2009, 169(6), 551-561.

[41] Garland, C. F., Gorham, E. D., Mohr, S. B., et al.: Vitamin D for cancer prevention: global perspective. Ann. Epidemiol., 2009, 19(7), 468-483.

[42] Bouillon, R., Van Schoor, N. M., Gielen, E., et al.: Optimal vitamin D status: a critical analysis on the basis of evidence-based medicine. J. Clin. Endocrinol. Metab., 2013, 98(8), E1283-E1304.

[43] Bischoff-Ferrari, H. A., Dawson-Hughes, B., Orave, E. J., et al.: Monthly high-dose vitamin D treatment for the prevention of functional decline: a randomized clinical trial. JAMA Intern. Med., 2016, 176(2), 175-183.

[44] Uusi-Rasi, K., Patil, R., Karinkanta, S., et al.: Exercise and vitamin $\mathrm{D}$ in fall prevention among older women: a randomized clinical trial. JAMA Intern. Med., 2015, 175(5), 703-711.

[45] Hansen, K. E., Johnson, R. E., Chambers, K. R., et al.: Treatment of vitamin $\mathrm{D}$ insufficiency in postmenopausal women: a randomized clinical trial. JAMA Intern. Med., 2015, 175(10), 16121621.

[46] Sanders, K. M., Stuart, A. L., Williamson, E. J., et al.: Annual high-dose oral vitamin D and falls and fractures in older women: a randomized controlled trial. JAMA, 2010, 303(18), 18151822.

[47] Dror, Y., Giveon, S. M., Hoshen, M., et al.: Vitamin D levels for preventing acute coronary syndrome and mortality: evidence of a nonlinear association. J. Clin. Endocrinol. Metab., 2013, 98(5), 2160-2167.

[48] Nestle, M., Nesheim, M. C.: To supplement or not to supplement: the U.S. Preventive Services Task Force recommendations on calcium and vitamin D. Ann. Intern. Med., 2013, 158(9), 701702 .

(Bajnok László dr., Pécs, Ifjúság útja 13., 7624 e-mail: bajnok.laszlo@.pte.hu 